\title{
Termite mounds house a diversity of taxa in oil palm plantations irrespective of understory management
}

Article

Accepted Version

Hood, A. S. C. ORCID: https://orcid.org/0000-0003-3803-0603,

Pashkevich, M. D., Dahlsjö, C. A. L., Advento, A. D., Agung Ketut Aryawan, A., Caliman, J.-P., Naim, M., Head, J. J. and Turner, E. C. (2020) Termite mounds house a diversity of taxa in oil palm plantations irrespective of understory management. Biotropica, 52 (2). pp. 345-350. ISSN 1744-7429 doi: https://doi.org/10.1111/btp.12754 Available at https://centaur.reading.ac.uk/96881/

It is advisable to refer to the publisher's version if you intend to cite from the work. See Guidance on citing.

Published version at: https://doi.org/10.1111/btp. 12754

To link to this article DOI: http://dx.doi.org/10.1111/btp.12754

Publisher: Wiley

All outputs in CentAUR are protected by Intellectual Property Rights law, including copyright law. Copyright and IPR is retained by the creators or other copyright holders. Terms and conditions for use of this material are defined in the End User Agreement. 


\section{CentAUR}

Central Archive at the University of Reading

Reading's research outputs online 
Hood et. al.

Biotropica Insight

Termite Mounds House a Diversity of Taxa in Oil Palm Plantations Irrespective of Understory Management

Amelia S. C. Hood ${ }^{1 *}$, Michael D. Pashkevich ${ }^{1}$, Cecilia A. L. Dahlsjö $^{2}$, Andreas D. Advento ${ }^{3}$, Anak Agung Ketut Aryawan ${ }^{3}$, Jean-Pierre Caliman ${ }^{3}$, Mohammad Naim ${ }^{3}$, Jason J. Head ${ }^{1}$, Edgar C. Turner ${ }^{1}$

1. Department of Zoology, University of Cambridge, Downing Street, Cambridge CB2 3EJ, UK

2. School of Geography and the Environment, University of Oxford, South Parks Road, Oxford, OX1 3QY, UK

3. Sinar Mas Agro Resources and Technology Research Institute (SMARTRI), Jalan Teuku Umar, No. 19, Pekanbaru 28112, Riau, Indonesia

*corresponding author: ah684@cam.ac.uk 
Hood et. al.

\section{ABSTRACT}

We investigated the effects of oil palm understory vegetation management on termite mound activity and non-termite inhabitants. We found a diversity of taxa, most of which were unaffected by understory management. Mound volume and termite activity had taxa-specific effects on abundance. Preserving mounds in oil palm plantations will benefit biodiversity.

\section{ABSTRACT IN INDONESIAN}

Kami menyelidiki efek manajemen vegetasi lantai di perkebunan kelapa sawit terhadap aktivitas rayap dan penghuni selain rayap dalam gundukan. Kami menemukan beragam taksa, yang sebagian besar tidak terpengaruh oleh manajemen vegetasi lantai. Volume gundukan dan aktivitas rayap memiliki efek taksa spesifik terhadap kelimpahan. Mempertahankan gundukan di perkebunan kelapa sawit akan menguntungkan biodiversitas.

\section{DATA AVAILABILITY STATEMENT}

The data used in this study are archived at the Dryad Digital Repository (DOI: 10.5061/dryad.b2rbnzs9g).

\section{KEY WORDS}

Elaeis guineensis, habitat heterogeneity, herbicide, Indonesia, Macrotermitinae, Macrotermes gilvus, termitaria, termitophile 
Hood et. al.

TEXT

The global demand for palm oil and resultant expansion of oil palm plantations are primary drivers of deforestation (Wicke et al. 2011) and biodiversity loss (Foster et al. 2011) in South East Asia. Sustainable management of monoculture crops that encourages biodiversity is therefore an important priority, highlighted by certification schemes such as the Roundtable on Sustainable Palm Oil (RSPO). Habitat complexity increases the abundance of microhabitats which in turn supports a higher diversity of organisms (Benton et al. 2003, Bennett et al. 2006, Seibold et al. 2016). In oil palm plantations, habitat complexity has been implemented by preserving forest patches, preserving and creating riparian buffers, and by enhancing understory vegetation (Lucey et al. 2014, Luke et al. 2018). The latter can grow up to several metres tall in mature oil palm plantations (Tan et al. 2014), and studies have shown that maintaining understory vegetation encourages plant, invertebrate and vertebrate biodiversity (Ashton-Butt et al. 2018, Hood et al. 2019, Luke, Purnomo, et al. 2019). Despite this, liberal use of herbicides which reduce, or altogether remove, the understory is common practice, with herbicides accounting for more than 90 percent of a typical plantation's pesticide inputs (Page \& Lord 2006).

Termites are ecosystem engineers that contribute to habitat resilience by reducing the effects of drought (Ashton et al. 2019) and promoting primary productivity (Jouquet et al. 2011). By doing so, termites promote biodiversity in the surrounding area too; for instance, termite mounds have been shown to support a diversity of animal species by acting as resting or nesting sites. Taxa associated with termite mounds include birds (Vasconcelos et al. 2015), mammals (Valdivia-Hoeflich et al. 2005), snakes (Riley et al. 1985, Moreira et al. 2009), lizards (Vitt et al. 2007), and invertebrates (De Visser et al. 2008). 
Hood et. al.

Termite diversity is limited in oil palm plantations due to their sensitivity to environmental variability, however, species of the fungus-growing Macrotermitinae that create protective mounds that buffer against habitat disturbance are relatively common (Lavelle et al. 2014, Luke et al. 2014). Although the presence of termites in oil palm plantations is valuable for soil moisture retention and nutrient cycling (Foster et al. 2011), mounds are often removed to ease harvesting access or because termites are mistakenly identified as pest species (Corley \& Tinker 2016).

In this study we investigate the effect of oil palm understory management on termite mound activity and the use of termite mounds by non-termite inhabitants, including their nest site preferences. We predict that plots with more understory vegetation will have a higher proportion of active mounds due to greater understory biomass, a food resource for fungusgrowing termites (Luke, Purnomo, et al. 2019). Additionally, since changes in understory management affect invertebrates and vertebrates (Ashton-Butt et al. 2018, Hood et al. 2019), we expect changes in non-termite inhabitants too.

Fieldwork was conducted in Sumatra, Indonesia $\left(0^{\circ} 56^{\prime} 0^{\prime \prime} \mathrm{N}, 101^{\circ} 18^{\prime} 0^{\prime \prime} \mathrm{E}, 10-30 \mathrm{~m}\right.$ a.s.l.) in oil palm plantations which are part of the Biodiversity and Ecosystem Function in Tropical Agriculture (BEFTA) Programme. The site was converted to oil palm from logged lowland rainforest between 1985 - 1995 and the climate has an average temperature and rainfall of $26.8^{\circ} \mathrm{C}$ and $2400 \mathrm{~mm}$ respectively. Across the plantation, oil palm has been planted in staggered rows at a density of $147 \mathrm{palms} / \mathrm{ha}$.

Three experimental understory management treatments were established in February 2014:

1. Reduced complexity where all understory vegetation was removed using herbicides.

2. Normal complexity where the management did not diverge from standard industry practice at the site. This included herbicide spraying of vegetation in harvesting paths 
Hood et. al.

and circles (1.5 m radius around the base of each tree). Large woody vegetation was removed manually.

3. Enhanced complexity where the understory vegetation in the harvesting paths and circles was cleared manually using a strimmer. No herbicide was employed in this treatment, and large woody vegetation was removed manually.

The treatment plots were each $150 \mathrm{~m}$ x $150 \mathrm{~m}$ and assigned in a randomised complete block design with four replicates. Plots within blocks were $150 \mathrm{~m}$ apart and the blocks were at least one kilometre apart (see Luke, Advento, et al. 2019 for full information on study site and experimental design).

We surveyed the centre of each plot (subplot: $66 \mathrm{~m} \times 66 \mathrm{~m}$ ) between April - May 2018 (only three normal plots were sampled). We measured mound height and radius, and by destructively searching 85 percent of the aboveground volume of each mound (Figure S1), we sampled mound activity (living or dead mounds) and the presence of any non-termite inhabitants. This destructive sampling did not cause any additional adverse impact on the environment as the plots were due to be replanted. Snakes and spiders were photographed in the field and identified to family (and species when possible) using taxonomic keys (Brown et al. 1999, Keogh et al. 2001, Dippenaar-Schoeman \& Jocqué 2007, De Lang 2017, World Spider Catalog 2017) (Figure S2). We recorded ant nests in the termite mounds of which two common genera (Odontomachus and Anoplolepis (species Anoplolepis gracilipes)) were identifiable in the field, while all other ant genera were classified as "other". Termites were identified using the key to termite species by Thapa (1981).

Only eight termite mounds were encountered across the three normal plots compared with 25 in the four enhanced plots and 31 in the four reduced plots. This variation was due to initial patchiness before the vegetation treatments were applied (personal observation). Due to the small sample size in the normal plots, we removed these from the analysis. We ran 
generalized linear mixed models (GLMM) in R (version 3.5.1) to determine the impact of understory management (enhanced and reduced) and mound size on termite mound activity, and ran further GLMMs with these three variables as predictors against the abundance of the most common non-termite inhabitants (ants, snakes, spiders, and centipedes) (Supplementary Material 1). Mound preference of snake families, spider families, and ant genera were analysed in relation to the treatments using two-tailed Fisher's Exact Tests (Ruxton \& Neuhäuser 2010).

We encountered one mound-building termite species, the fungus-growing Macrotermes gilvus. Across the treatment plots (reduced and enhanced) the termite mounds had an average volume and density of $5.4 \pm 3.4 \mathrm{~m}^{3}$ and $16.4 \pm 4.7 /$ ha respectively, and 57 percent of mounds were active. The four most commonly encountered taxa were snakes (44 individuals, 11 nests), spiders (39 individuals, 6 nests), centipedes (71 individuals), and ants (48 nests). Snake species Ramphotyphlops lineatus (Lined Blind Snake), Pseudorabdion longiceps (Dwarf Reed Snake), and Naja sumatrana (Equatorial Spitting Cobra) were found nesting with eggs in the mounds, and Python brongersmai (Brongersma's Short-Tailed Python) was found resting. Scorpions, beetles, cockroaches, and earthworms were also encountered, but these were too rare to be included in the analysis.

Model comparison (using AIC, Supplementary Material 1) indicated that vegetation treatment did not impact mound activity or the total abundance of the four most common inhabitants, and it was removed from the final models. Mound volume did not impact mound activity either, and it was removed, and the null model was chosen. Mound volume and activity did impact total non-termite inhabitant abundance. Snake abundance increased with mound volume but decreased with mound activity, while ant nest abundance decreased with mound volume (Figure 1, Table S1). Neither mound activity nor volume had a significant impact on spiders. Mound activity was included in the final model for centipede abundance, 
but its effect was not significant (Figure 1, Table S1). Although the treatments did not impact the total abundance of the most common groups, the composition of snake families $(P=$ 0.005 , Fisher's exact test $)$ and ant genera $(P=0.016$, Fisher's exact test $)$ were affected by the treatments, with more Colubridae and fewer Typhlopidae and Anopololepis in the enhanced than the reduced plots (Figure 2). The composition of spider families was not affected by the treatments $(P=0.420$, Fisher's exact test, Figure 2$)$.
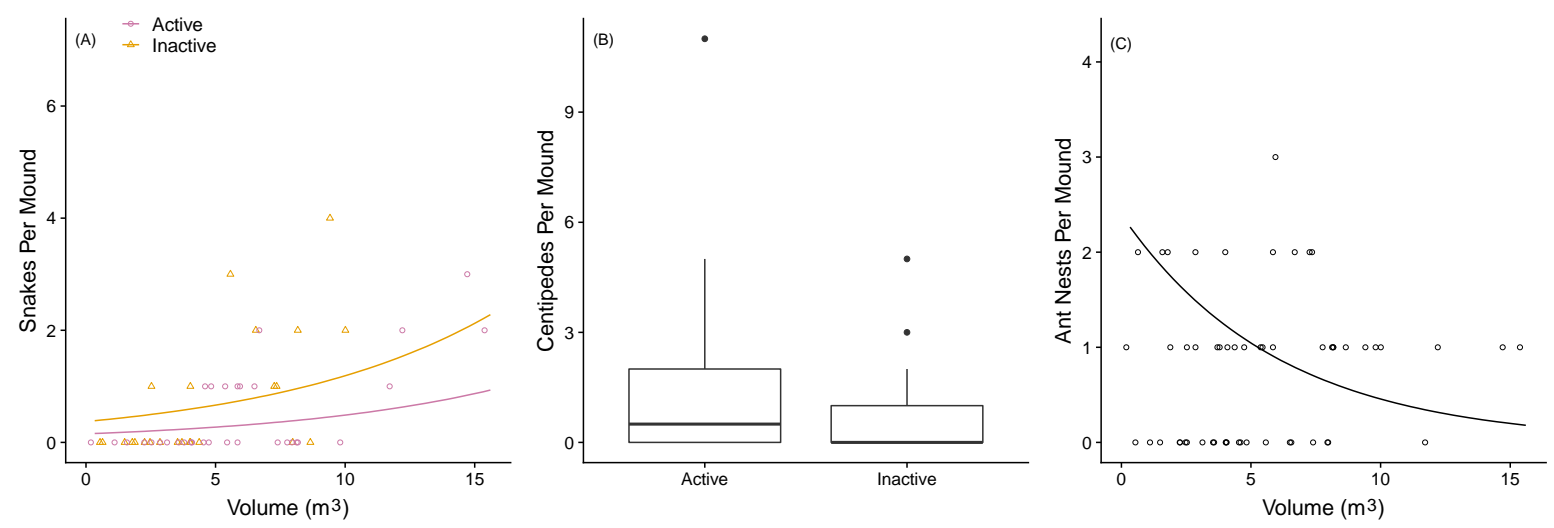

FIGURE 1. The abundance per mound of: (A) snakes by volume for active and inactive mounds;

(B) centipedes by mound activity; and (C) ant nests by volume. Shaded areas show 95 percent confidence intervals around lines of best fit (Supplementary Information 1). Each point shows a single termite mound. Although there was a trend for increased centipede abundance in active mounds $(\mathrm{B}, \mathrm{P}=0.06)$, this relationship was not significant when an outlier was removed $(\mathrm{P}=0.57$, see Table $\mathrm{S} 1)$. 

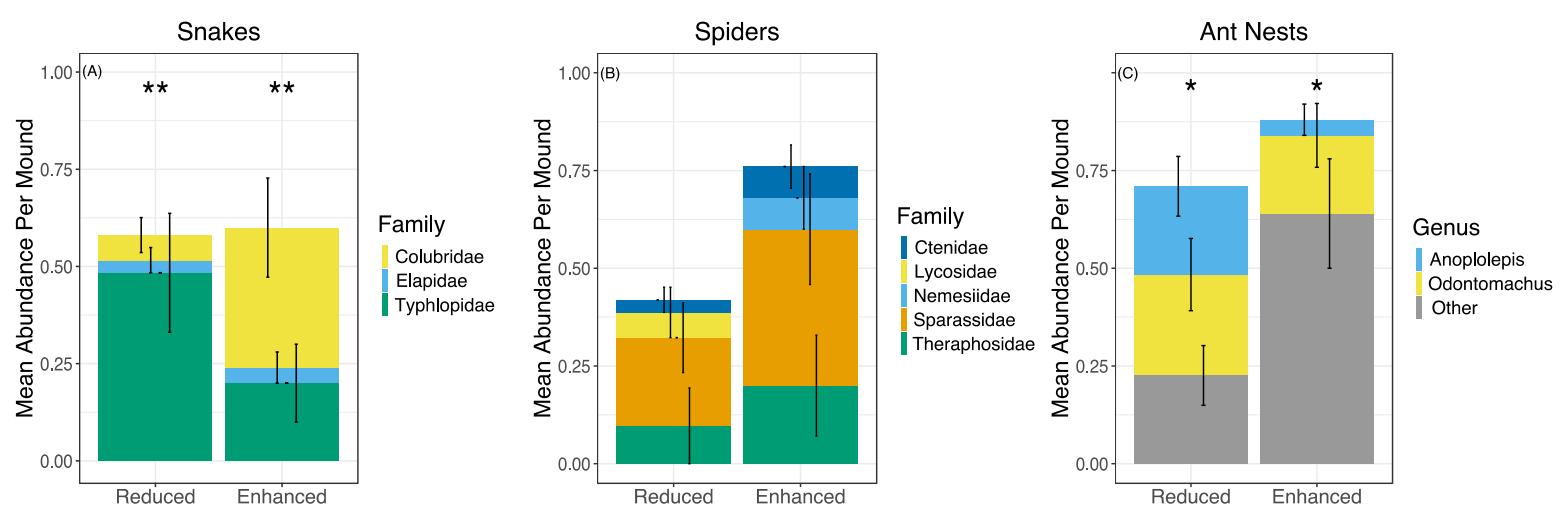

FIGURE 2. Mean abundance per mound of: (A) snake families; (B) spider families; and (C) ant nests (sorted to genera and including group "Other" for those that were not identified) by vegetation treatment (reduced and enhanced). Asterisks show significant differences in group composition, according to Fisher's Exact tests. Significance codes are: $\mathrm{P}<0.01^{* *}, \mathrm{P}<0.05^{*}$. Error bars show standard error.

The mound building termite $M$. gilvus was the sole contributor to the mounds in the study site. It belongs to the most commonly encountered termite subfamily (Macrotermitinae) in oil palm plantations in South East Asia (Luke et al. 2014, Wong et al. 2016). Understory vegetation management did not impact the activity of termite mounds in the plantation, suggesting that $M$. gilvus is highly resilient to anthropogenic disturbance, habitat simplification and resource removal. There was also little impact of vegetation removal on non-termite mound inhabitants, indicating that termite mounds provide important nesting sites in different habitats. As abundances of species outside the mounds were not examined, we are unable to comment on the preference of termite mounds as nesting sites compared with other microhabitats. However, this study supports previous work that has found termite mounds act as refuges for a range of animals (Choosai et al. 2009, Joseph et al. 2013, 2015).

It is also noteworthy that the abundance and diversity of snakes in the termite mounds was surprisingly high. While snakes have been found to rest in termite mounds (Angelici et 
al. 2000, Duleba \& Ferreira 2014) evidence of nesting within mounds is scarce (but see Riley et al. 1985). To our knowledge, this is the first example of Elapidae and Pythonidae using mounds in this manner. Benefits of nesting in mounds include protection against predators (Brightsmith 2000), microbes or parasites (Kalko et al. 2006), the provision of a stable environment (King et al. 2017) (which is particularly important for egg development (Knapp \& Owens 2008)), and food for insectivorous species (Vitt et al. 2007). However, as fewer snakes were recorded in active mounds, the latter benefit was most likely not a primary driver of nest site selection. The increase in snake abundance in larger mounds, on the other hand, suggests that microclimatic protection was an important driver, as larger mounds buffer temperature more effectively (Vesala et al. 2019). Preference for larger termite nests has been observed in other taxa too, such as birds (Brightsmith 2000).

In contrast to snakes, the abundance of ant nests was higher in small termite mounds. This may be due to the selection of warmer habitats by ants, as smaller termite mounds tend to have poorer heat regulation (Vesala et al. 2019). Additionally, termite predation by ants is widespread (Prestwich 1984, Berghoff et al. 2002) and termites are therefore expected to be on high alert regarding ant intrusion. As larger termite mounds comprise a higher number of individuals, they may reduce the success of nest establishment due to better defence. Neither centipedes nor spiders were affected by termite mound activity or size, suggesting that their presence in the mounds may not trigger a termite response.

Our results suggest that termite mounds are resilient to habitat disturbance and resource removal and that they provide suitable nesting sites for animals in oil palm plantations. Without better understanding of the abundance of non-termite mound inhabitants in the surrounding habitat, we are unable to quantify the importance of termite mounds as nesting sites. However, we suggest that the removal of understory vegetation provides fewer microhabitats and therefore a reduced number of nesting spots compared with areas where 
vegetation is allowed to grow. It is therefore likely that the presence of termite mounds in simplified habitats provide shelter for a larger proportion of the overall biodiversity. This possibility should be tested.

While the resilience of termite mounds allows for animals to take advantage of them regardless of habitat management, mounds are often removed during harvest and plantation replanting. As millions of hectares of oil palm plantations are now due to be replanted (Snaddon et al. 2013), we must urgently determine the vulnerability of termites and their mounds to the replanting process in oil palm plantations. The current replanting process involves clearing vast swathes of land, resulting in hectares of homogenous exposed soil and subsequent biodiversity loss (Kurz et al. 2016, Ashton-Butt et al. 2019). Actively retaining a range of mound sizes through this process will provide an important habitat for species. Efforts should be made to improve understanding amongst plantation managers and workers of the value of mound-building termites in plantations. This will allow for better identification of pest species (Corley \& Tinker 2016) and enable termite mounds to be actively conserved during management operations to maintain potential associated benefits to decomposition (Foster et al. 2011), soil stability and biodiversity.

\section{ACKNOWLEDGEMENTS}

We thank Pt. Ivo Mas Tunggal and Golden Agri Resources, and Sinar Mas Agro Resources Technology Research Institute (SMARTRI) for permission to work in their plantations. We thank the staff at SMARTRI and the local estate workers for all their hard work, with special thanks to Wahyu Rizky Suberkah for his advice throughout the project. We thank Sarah H Luke, Andrew J Bladon, and our three reviewers for their comments on the manuscript, and Martina F Harianja for translating the abstract into Indonesian. We thank CJ Bell, University of Texas at Austin, for access to literature. We are grateful to RISTEK for granting us 
Hood et. al.

research permission (permit numbers 426/SIP/FRP/SM/XI/2012,

72/EXT/SIP/FRP/SM/IX/2013, 44/EXT/SIP/FRP/SM/IX/2014, 52/SIP/FRP/E5/Dit.KI/II/2017, 09/EXT/SIP/FRP/E5/Dit.KI/II/2018), and to Sudharto PS for his assistance with applications (local collaborator). We thank the Whitten Studentship and The Tim Whitmore Zoology Fund from the Department of Zoology, University of Cambridge; the Isaac Newton Fund; SMARTRI; and Gates Cambridge Trust for funding this research.

\section{AUTHOR CONTRIBUTION STATEMENT}

$\mathrm{AH}$ and ET conceived the study. AH, ADA and AAKA collected the data, with input from ET, JP and MN on study design. MP, CD and JH identified the animals. AH wrote the original draft, and all authors reviewed and edited it.

\section{CONFLICT OF INTEREST}

Co-authors listed with a Sinar Mas Agro Resources and Technology Research Institute (SMARTRI) affiliation were employed by SMARTRI, the research division of Golden Agri Resources (GAR), at the time of the study. The wider BEFTA Programme is co-funded by GAR. However, there is an MOU in place that protects the intellectual freedom and data-use for all researchers working on the project. The Programme therefore represents a collaboration between the University of Cambridge and an oil palm company, ensuring that results are readily disseminated to inform best management practices, but maintaining academic independence.

\section{LITERATURE CITED}

ANGelici, F. M., C. EFFAH, M. AKPAN INYANG, and L. LuiSELli. 2000. A preliminary 
Hood et. al.

radiotracking study of movements, activity patterns and habitat use of free-ranging Gaboon vipers, Bitis Gabonica. Rev. d'Ecologie (La Terre la Vie) 55: 45-55.

Ashton-Butt, A., A. A. K. Aryawan, A. S. C. Hood, M. Naim, D. Purnomo, Suhardi, R.

Wahyuningsih, S. Willcock, G. M. Poppy, J.-P. CAliman, E. C. TuRner, W. A.

Foster, K. S.-H. PeH, and J. L. SnAdDON. 2018. Understory Vegetation in Oil Palm

Plantations Benefits Soil Biodiversity and Decomposition Rates. Front. For. Glob.

Chang. 1. Available at: https://www.frontiersin.org/article/10.3389/ffgc.2018.00010/full.

Ashton-Butt, A., S. Willcock, D. Purnomo, Suhardi, A. A. K. Aryawan, R.

Wahyuningsih, M. NAim, G. M. Poppy, J.-P. Caliman, K. S.-H. Peh, and J. L.

SNADDON. 2019. Replanting of first-cycle oil palm results in a second wave of

biodiversity loss. Ecol. Evol. 9: 6433-6443. Available at:

https://onlinelibrary.wiley.com/doi/abs/10.1002/ece3.5218.

Ashton, L. A., H. M. Griffiths, C. L. PARr, T. A. Evans, R. K. Didham, F. Hasan, Y. A.

TEH, H. S. Tin, C. S. VAIRAPPAn, and P. Eggleton. 2019. Termites mitigate the effects of drought in tropical rainforest. Science (80-. ). 363: 174-177.

BenNetT, A. F., J. Q. RADFORD, and A. HASLEM. 2006. Properties of land mosaics:

Implications for nature conservation in agricultural environments. Biol. Conserv. 133: $250-264$.

BENTON, T. G., J. A. ViCKERY, and J. D. WiLsON. 2003. Farmland biodiversity: Is habitat heterogeneity the key? Trends Ecol. Evol. 18: 182-188.

Berghoff, S. M., A. Weissflog, K. E. Linsenmair, R. Hashim, and U. Maschwitz. 2002.

Foraging of a hypogaeic army ant : a long neglected majority. Insectes Soc. 49: 133141.

BRIGHTSMITH, D. J. 2000. Use of arboreal termitaria by nesting birds in the Peruvian Amazon. Condor 102: 529-538. Available at: 
Hood et. al.

http://www.bioone.org/doi/abs/10.1650/0010-

5422(2000)102\%5B0529:UOATBN\%5D2.0.CO;2\%5Cnhttp://elibrary.unm.edu/sora/Co ndor/files/issues/v102n03/p0529-p0538.pdf.

Brown, R. M., A. E. LEVITON, and R. V. Sison. 1999. Description of a new species of Pseudorabdion (Serpentes:Colubridae) from Panay Island, Philippines with a revised key to the genus. Asiat. Herpetol. Res. 8: 7-12.

Choosai, C., J. Mathieu, Y. Hanboonsong, and P. JouQuet. 2009. Termite mounds and dykes are biodiversity refuges in paddy fields in north-eastern Thailand. Environ. Conserv. 36: 71-79.

Corley, R. H. V, and P. B. TinKer. 2016. Pests of the Oil Palm. In Blackwell Science Ltd. (Ed.) The Oil Palm. pp. 437-459, Wiley Blackwell.

DIPPENAAR-SCHOEMAN, A. S., and R. JOCQUÉ. 2007. Spider families of the world.

DulEBA, S., and V. L. FERREIRA. 2014. Herpetofauna associated with termite mounds in a pasture, Mato Grosso do Sul State, Brazil. Herpetol. Bull. 10-16.

Foster, W. A., J. L. Snaddon, E. C. Turner, T. M. FAyle, T. D. Cockerill, M. D. F. Ellwood, G. R. Broad, A. Y. C. Chung, P. Eggleton, C. V. Khen, and K. M. Yusah. 2011. Establishing the evidence base for maintaining biodiversity and ecosystem function in the oil palm landscapes of South East Asia. Philos. Trans. R. Soc. B Biol. Sci. 366: 3277-3291.

Hood, A. S. C., A. A. K. Aryawan, A. D. Advento, D. Purnomo, R. Wahyuningsih, S. H. Luke, S. Ps, J. L. Snaddon, W. A. Foster, J.-P. CAliman, E. C. Turner, and M. NAim. 2019. Understory Vegetation in Oil Palm Plantations Promotes Leopard Cat Activity, but Does Not Affect Rats or Rat Damage. Front. For. Glob. Chang. 2. Available at: https://www.frontiersin.org/article/10.3389/ffgc.2019.00051/full.

Joseph, G. S., M. Makumbe, C. L. Seymour, G. S. Cumming, Z. Mahlangu, and D. H. M. 
Hood et. al.

CUMMING. 2015. Termite mounds mitigate against 50 years of herbivore-induced reduction of functional diversity of savanna woody plants. Landsc. Ecol. 30: 2161-2174. Joseph, G. S., C. L. Seymour, G. S. Cumming, Z. Mahlangu, and D. H. M. Cumming. 2013. Escaping the flames: Large termitaria as refugia from fire in miombo woodland. Landsc. Ecol. 28: 1505-1516.

Jouquet, P., S. Traoré, C. Choosai, C. Hartmann, and D. Bignell. 2011. Influence of termites on ecosystem functioning. Ecosystem services provided by termites. Eur. J. Soil Biol. 47: 215-222.

KALKo, E. K. V, K. UeberschaER, and D. DeChMANN. 2006. Roost structure, modification, and availability in the white-throated round-eared bat, Lophostoma silvicolum(Phyllostomidae) living in active termite nests. Biotropica 38: 398-404.

KEOGH, J. S., D. G. BARKER, and R. SHINE. 2001. Heavily exploited but poorly known: systematics and biogeography of commercially harvested pythons (Python curtus group) in Southeast Asia. Biol. J. Linn. Soc. 73: 113-129.

King, H., S. A. OCKO, and L. MAHADEVAN. 2017. Termite mounds harness diurnal temperature oscillations for ventilation. PNAS 112: 11589-11593. Available at: http://arxiv.org/abs/1703.08067.

KNAPP, C. R., and A. K. OWENS. 2008. Nesting Behavior and the Use of Termitaria by the Andros Iguana (Cyclura Cychlura Cychlura). J. Herpetol. 42: 46-53.

Kurz, D. J., E. C. Turner, A. A. Aryawan, H. C. Barkley, J. Caliman, O. Konopik, S. PS, and W. A. FOSTER. 2016. Replanting reduces frog diversity in oil palm. Biotropica 48: 483-490.

DE LANG, R. 2017. The Snakes of Java, Bali and Surrounding Islands. Edition Chimaira. Lavelle, P., N. Rodríguez, O. Arguello, J. Bernal, C. Botero, P. Chaparro, Y. Gómez, A. Gutiérrez, M. Del P. Hurtado, S. Loaiza, S. X. Pullido, E. RodríGuez, 
C. SANABRIA, E. VelásQueZ, and S. J. FonTE. 2014. Soil ecosystem services and land use in the rapidly changing Orinoco River Basin of Colombia. Agric. Ecosyst. Environ. 185: 106-117. Available at: http://dx.doi.org/10.1016/j.agee.2013.12.020.

Lucey, J. M., N. Tawatao, M. J. M. Senior, C. V. Khen, S. Benedick, K. C. Hamer, P. Woodcock, R. J. Newton, S. H. Bottrell, and J. K. HiLl. 2014. Tropical forest fragments contribute to species richness in adjacent oil palm plantations. Biol. Conserv. 169: 268-276. Available at: http://dx.doi.org/10.1016/j.biocon.2013.11.014.

LUKE, S. H. ET AL. 2019. Managing oil palm plantations more sustainably: large-scale experiments within the Biodiversity and Ecosystem Function in Tropical Agriculture (BEFTA) Programme. Front. For. Glob. Chang.

Luke, S. H., T. M. Fayle, P. Eggleton, E. C. Turner, and R. G. Davies. 2014. Functional structure of ant and termite assemblages in old growth forest, logged forest and oil palm plantation in Malaysian Borneo. Biodivers. Conserv. 23: 2817-2832. Available at: http://link.springer.com/10.1007/s10531-014-0750-2.

Luke, S. H., D. Purnomo, A. D. Advento, A. A. K. Aryawan, M. Naim, R. N. Pikstein, S. Ps, T. D. S. Rambe, Soeprapto, J. Caliman, J. L. Snaddon, W. A. Foster, and E. C. TURNER. 2019. Effects of understory vegetation management on plant communities in oil palm plantations in Sumatra, Indonesia. Front. For. Glob. Chang. 2.

Luke, S. H., E. M. Slade, C. L. Gray, K. V. Annammala, J. Drewer, J. Williamson, A. L. Agama, M. Ationg, S. L. Mitchell, C. S. Vairappan, and M. J. Struebig. 2018. Riparian buffers in tropical agriculture: Scientific support, effectiveness, and directions for policy. J. Appl. Ecol. 1-8. Available at: http://doi.wiley.com/10.1111/13652664.13280.

Moreira, L., D. FenOlio, H. L. R. Silva, and N. J. DA Silva JR. 2009. A preliminary list of the Herpetofauna from termite mounds of the cerrado in the Upper Tocantins river 
valley. Pap. Avulsos Zool. 49: 183-189.

PAGE, B., and S. LORD. 2006. The Oil Palm Industry's approach to the use of pesticides in Papua New Guinea. Plant. 82: 1-10.

Prestwich, G. D. 1984. Defense Mechanisms of Termites. Annu. Rev. Entomol. 29: 201232. Available at:

http://www.annualreviews.org/doi/10.1146/annurev.en.29.010184.001221.

Riley, J., A. F. STIMSON, and J. M. WinCH. 1985. A review of Squamata ovipositing in ant and termite nests. Herpetol. Rev. 16: 38-43.

RUXTON, G. D., and M. NEUHÄUSER. 2010. Good practice in testing for an association in contingency tables. Behav. Ecol. Sociobiol. 64: 1505-1513. Available at: http://link.springer.com/10.1007/s00265-010-1014-0.

Seibold, S., C. BÄssler, R. Brandl, B. Büche, A. Szallies, S. Thorn, M. D. Ulyshen, and J. MÜLLER. 2016. Microclimate and habitat heterogeneity as the major drivers of beetle diversity in dead wood C. Baraloto (Ed.). J. Appl. Ecol. 53: 934-943. Available at: http://doi.wiley.com/10.1111/1365-2664.12607.

SNADDON, J. L., K. J. WILlis, and D. W. MACDONALD. 2013. Oil-palm replanting raises ecology issues. Nature 502: 170.

TAN, K. P., K. D. KANNIAH, and A. P. CRACKNELl. 2014. On the upstream inputs into the MODIS primary productivity products using biometric data from oil palm plantations. Int. J. Remote Sens. 35: 2215-2246. Available at: http://dx.doi.org/10.1080/01431161.2014.889865.

THAPA, R. S. 1981. Termites of Sabah (East Malaysia). Sabah Forest Department.

VAldiviA-Hoeflich, T., J. H. Vega Rivera, and K. E. StOner. 2005. The Citreoline Trogon as an Ecosystem Engineer. Biotropica 37: 465-467.

Vasconcelos, M. F., D. Hoffmann, M. C. ARaújo, and P. N. VASCOnCelos. 2015. Bird- 
termite interactions in Brazil: A review with perspectives for future studies. Biota

Neotrop. 15: 1-22. Available at: http://www.scopus.com/inward/record.url?eid=2-s2.084922339674\&partnerID=tZOtx3y1.

Vesala, R., A. Harjuntausta, A. Hakkarainen, P. Rönnholm, P. Pellikka, and J.

RIKKINEN. 2019. Termite mound architecture regulates nest temperature and correlates with species identities of symbiotic fungi. PeerJ 6: e6237. Available at: https://peerj.com/articles/6237.

De Visser, S. N., B. P. Freymann, and H. Schnyder. 2008. Trophic interactions among invertebrates in termitaria in the African savanna: A stable isotope approach. Ecol. Entomol. 33: 758-764.

VitT, L. J., D. B. Shepard, J. P. CAlDwell, G. H. C. Vieira, F. G. R. FranÇA, and G. R. CoLLI. 2007. Living with your food: Geckos in termitaria of Cantão. J. Zool. 272: 321328.

Wicke, B., R. SiKKEMA, V. DoRnBURG, and A. FAAIJ. 2011. Exploring land use changes and the role of palm oil production in Indonesia and Malaysia. Land use policy 28: 193-206. Available at: http://dx.doi.org/10.1016/j.landusepol.2010.06.001.

Wong, M. K., J. TSUKAmoto, Y. YUSUYin, S. TANAKA, K. IWASAKI, and N. P. TAN. 2016. Comparison of soil macro-invertebrate communities in Malaysian oil palm plantations with secondary forest from the viewpoint of litter decomposition. For. Ecol. Manage. 381: 63-73. Available at: http://dx.doi.org/10.1016/j.foreco.2016.09.011. World SpIDER CATAlOG. 2017. World Spider Catalog. Version 15.5 online at http://wsc.nmbe.ch, version 18.0, access. 
Hood et. al.

\section{SUPPLEMENTARY INFORMATION}

Supplementary Information 1. Shows the specifics of the two models and their outputs. For Eqn 1 we used a binomial distribution and a logit link as the data were binary. For Eqn 2 we used a Poisson distribution and a log link as the data were in counts. We included the random effect Plot, but not Block as it would have only had four levels. For Eqn 2 we included an offset of the logarithm of mound volume to convert abundance per mound to density per volume sampled. Therefore, dependent variables were density of the most common groups. Data exploration was conducted following Zuur et. al. 2010, and model construction and validation were conducted following Zuur \& Ieno 2016. We simplified the models by selecting those with the lowest Akaike's Information Criterion (AIC). Where $\Delta<2$, we applied the nesting rule, and discarded models that were more complicated versions of those that had a lower AIC value (Richards et. al. 2011). We simplified all models, even those with single predictors, by comparing them to intercept-only models. When modelling centipede density, we found that one of the points was highly influential (Cook's distance $>1$ ), so we removed this point and reran the analysis. We used R Studio version 1.0.153 (RStudio Team 2016) with packages tidyverse (Wickham 2017) and cowplot (Wilke 2019) for data wrangling and plotting, and packages influence.ME (Nieuwenhuis et. al. 2012), lme4 (Bates et. al. 2015), and glmmTMB (Brookes et. al. 2017) for constructing and validating models.

$$
\begin{aligned}
& \text { Activity }_{\mathrm{ij}} \sim \operatorname{Binomial}\left(\pi_{\mathrm{ij}}, \mathrm{N}_{\mathrm{ij}}, \phi\right) \\
& \mathrm{E}\left(\text { Activity }_{\mathrm{ij}}\right)=\pi_{\mathrm{ij}} * \mathrm{~N}_{\mathrm{ij}} \\
& \operatorname{Var}\left(\text { Activity }_{\mathrm{ij}}\right)=\pi_{\mathrm{ij}} * \mathrm{~N}_{\mathrm{ij}} *\left(1-\pi_{\mathrm{ij}}\right) \\
& \operatorname{logit}\left(\mathrm{P}_{\mathrm{ij}}\right)=\text { Understory }_{\mathrm{ij}}+\text { Plot }_{\mathrm{i}}
\end{aligned}
$$

Where: 
Activity $_{\mathrm{ij}}$ (mound activity: categorical, 2 levels) is the $j$ th observation in plot $I$, and $J=1, \ldots$, 56

Plot $t_{i}$ is the random intercept, and $I=1, \ldots, 11$

Understory is understory vegetation treatment: categorical, 2 levels

$$
\begin{aligned}
& \text { Abundance }_{\mathrm{ij}} \sim \operatorname{Poisson}\left(\mu_{\mathrm{ij}}\right) \\
& \mathrm{E}\left(\text { Abundance }_{\mathrm{ij}}\right)=\mu_{\mathrm{ij}} \\
& \operatorname{Var}\left(\text { Abundance }_{\mathrm{ij}}\right)=\mu_{\mathrm{ij}} \\
& \log \left(\mu_{\mathrm{ij}}\right)=\text { Understory }_{\mathrm{ij}}+\text { Activity }_{\mathrm{ij}}+\text { Volume }_{\mathrm{ij}}+\operatorname{offset}\left(\text { Volume }_{\mathrm{ij}}+\text { Plot }_{\mathrm{i}}\right.
\end{aligned}
$$

Where:

Abundance $\mathrm{ij}_{\mathrm{ij}}$ (abundance of spiders, ant nests, centipedes or snakes: continuous) is the $j$ th observation in plot $I$, and $J=1, \ldots, 56$

Plot $_{\mathrm{i}}$ is the random intercept, and $I=1, \ldots, 11$

Understory is understory vegetation treatment: categorical, 2 levels

Activity is mound activity: categorical, 2 levels

Volume is volume of soil searched: continuous

Supplementary Information 1 Literature Cited

BATES, D., M. MÄCHLER, B. BOLKER, and S. WALKER. 2015. Fitting Linear Mixed-Effects Models Using lme4. J. Stat. Softw. 67: 1-48. Available at: http://lme4.r-forge.rproject.org/lMMwR/lrgprt.pdf.

Brooks, M. E., K. Kristensen, K. J. van Benthem, A. Magnusson, C. W. Berg, A.

Nielsen, H. J. Skaug, M. MAEChleR, and B. M. BolKer. 2017. glmmTMB Balances Speed and Flexibility Among Packages for Zero-inflated Generalized Linear Mixed 
Hood et. al.

Modeling. R J. 9: 378-400.

NiEuwenhuis, R., M. TE Grotenhuis, and B. PELZER. 2012. influence.ME: Tools for

Detecting Influential Data in Mixed Effects Models. R J. 4: 38-47.

Richards, S. A., M. J. WhitTinghaM, and P. A. StePhENS. 2011. Model selection and model averaging in behavioural ecology: the utility of the IT-AIC framework. Behav. Ecol.

Sociobiol. 65: 77-89. Available at: http://link.springer.com/10.1007/s00265-010-1035-

8.

RSTUdio TEAm. 2016. RStudio: Integrated Development for R. RStudio, Inc. Available at: http://www.rstudio.com/.

WICKHAM, H. 2017. tidyverse: Easily Install and Load the 'Tidyverse'. R package version 1.2.1. Available at: https://cran.r-project.org/package=tidyverse.

WILKE, C. O. 2019. cowplot: Streamlined Plot Theme and Plot Annotations for 'ggplot2'. Available at: https://cran.r-project.org/package=cowplot.

ZUUR, A. F., and E. N. IENO. 2016. A protocol for conducting and presenting results of regression-type analyses. Methods Ecol. Evol. 7: 636-645.

ZuUR, A. F., E. N. IENO, and C. S. ELPHICK. 2010. A protocol for data exploration to avoid common statistical problems. Methods Ecol. Evol. 1:3-14. Available at: http://doi.wiley.com/10.1111/j.2041-210X.2009.00001.x.

Table S1. Estimated regression parameters, standard errors, $z$-values and $P$-values for the Poisson GLMMs presented in Eqn2 above. These are the simplified models, all initial models looked at the effect of vegetation treatment, mound volume, and activity on the four most abundant groups (snakes, spiders, centipedes and ants). All predictors were removed for the spider model. Two models are shown for centipede abundance, as the results differed when an 
influential outlier was removed. Significance codes are: $\mathrm{P}<0.001^{* * *}, \mathrm{P}<0.01^{* *}, \mathrm{P}<0.05^{*}$, $\mathrm{P}<0.1^{\prime}$

\begin{tabular}{|c|c|c|c|c|c|c|}
\hline \multirow[t]{2}{*}{ Group } & \multirow[t]{2}{*}{$\sigma_{\text {Plot }}$} & & \multirow[t]{2}{*}{ Estimate } & Std. & $Z$ & \multirow[t]{2}{*}{$P$-value } \\
\hline & & & & error & value & \\
\hline \multirow[t]{3}{*}{ Snakes } & $3 \times 10^{-9}$ & Intercept & -2.94 & 0.36 & -8.29 & $<0.001 * * *$ \\
\hline & & Volume $^{1}$ & 0.39 & 0.17 & 2.25 & $0.024 *$ \\
\hline & & Active & -0.89 & 0.38 & -2.34 & $0.020 * *$ \\
\hline \multirow[t]{2}{*}{ Centipedes } & 0.133 & Intercept & -1.46 & 0.21 & -7.08 & $<0.001 * * *$ \\
\hline & & Active & 0.57 & 0.30 & 1.88 & $0.060^{\prime}$ \\
\hline Centipedes: & 0.032 & Intercept & -1.67 & 0.19 & -9.02 & $<0.001 * * *$ \\
\hline No Outlier & & Active & 0.17 & 0.30 & 0.57 & 0.567 \\
\hline \multirow[t]{2}{*}{ Ants } & $8 \times 10^{-9}$ & Intercept & -1.71 & 0.15 & -11.26 & $<0.001 * * *$ \\
\hline & & Volume $^{1}$ & -0.56 & 0.17 & -3.25 & $0.001 * *$ \\
\hline
\end{tabular}

${ }^{1}$ Volume $=$ Standardised Mound Volume 
Hood et. al.

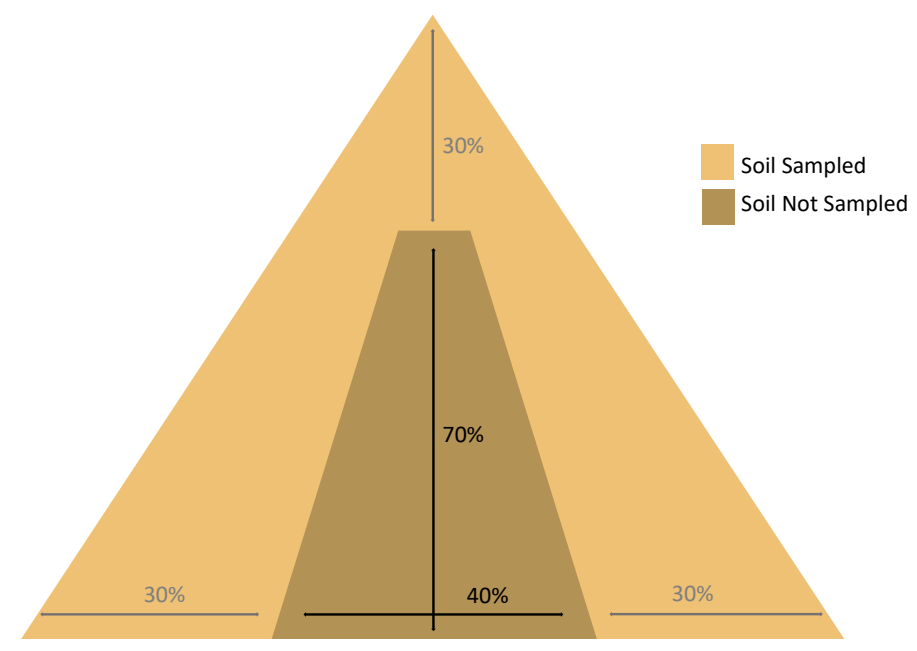

Figure S1. Diagram showing the proportion of each termite mound that was manually searched. We removed the outer and upper 30 percent of each mound. Assuming that the mounds were cones (i.e. their volume was $\pi^{*}$ radius $^{2 *}$ height/3), the soil sampled amounted to 85 percent of the total volume of the mound. 


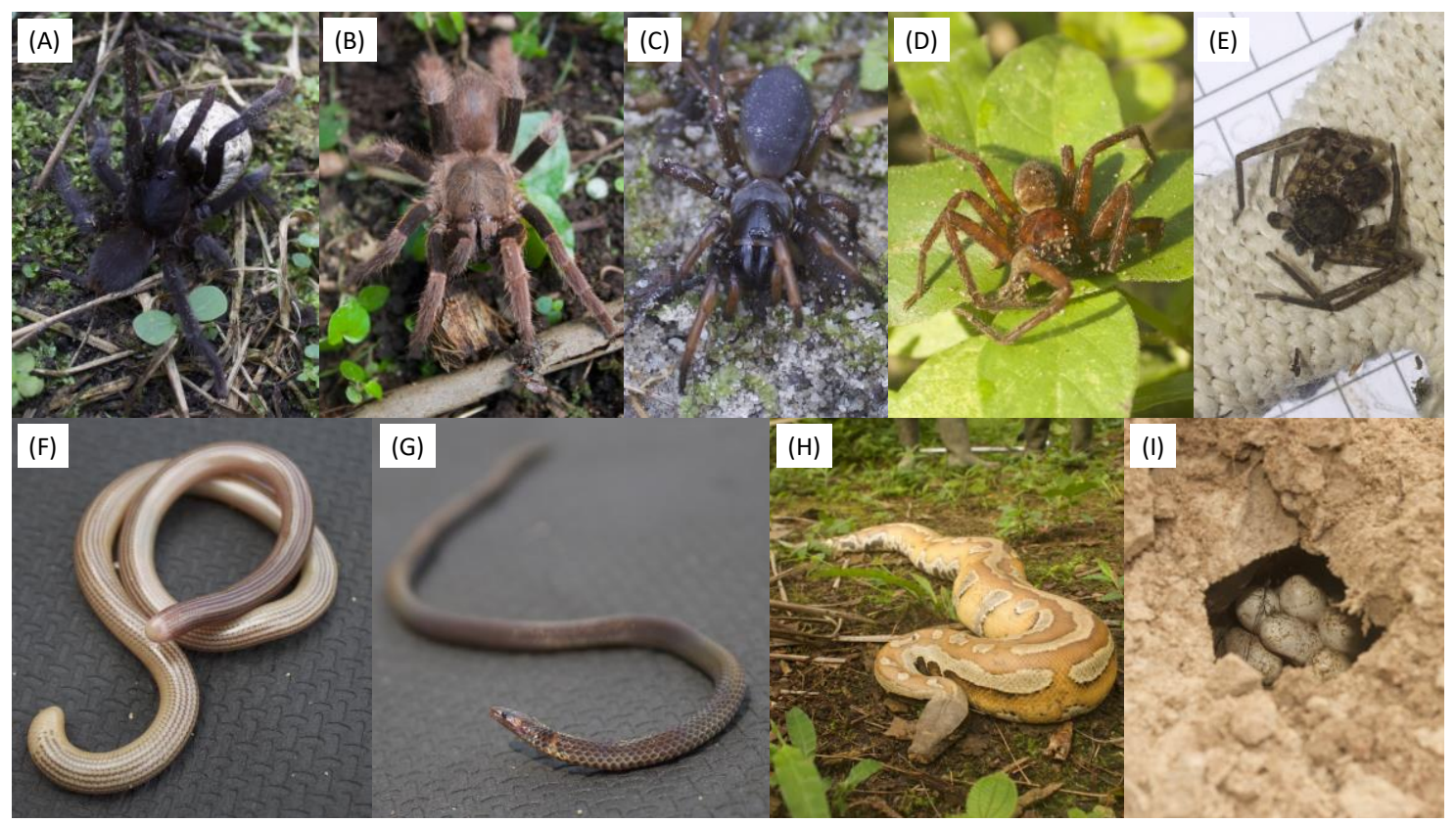

Figure S2. Photos of spiders from family: (A) Theraphosidae with egg sack; (B) Theraphosidae; (C) Nemesiidae; (D) Sparassidae; and (E) Sparassidae. Photos of snake species: (F) Ramphotyphlops lineatus; (G) Pseudorabdion longiceps; (H) Python Cf. brongersmai; and a (I) Naja sumatrana nest. 